\title{
Route Construction of Innovation and Entrepreneurship Education Development in Universities of Western China against the Belt and Road Initiative
}

\author{
Chang Lang \\ School of International Studies, Yanan University \\ Yanan, Shaanxi, 716000
}

\begin{abstract}
The Belt and Road (B\&R initiative) is a comprehensive initiative to deepen reform and opening up, and is of great significance for the development of in-depth economic globalization of China. And large-scale innovation and entrepreneurship talents are the key factors in promoting the economic globalization. Western China, as the starting point of Silk Road, should proactively adapt to the need of B\&R initiative. As the base of higher innovation and entrepreneurship talents, Western colleges and universities in China should give full play to the cultivation of innovative and entrepreneurial talents, fully understand the significance of innovation and entrepreneurship of $B \& R$ initiative, accurately grasp the compatibility features between $B \& R$ initiative and innovation and entrepreneurship education, and finally achieve the role of innovation and entrepreneurship education in fostering talents from aspects such as concept changing, region basing, quality improving, policy implementing, and system perfecting.
\end{abstract}

Keywords-B\&R initiative; Western regions; Innovation and entrepreneurship education; Route

\section{INTRODUCTION}

On September 7, 2013, Chairman Xi Jinping addressed at Nazarbayev University, "My hometown is in Shaanxi which is the beginning of the ancient Silk Road. Today, as I stand here and look back at that episode of history, I could almost hear the camel bells echoing in the mountains and see the wisp of smoke rising from the desert." Shaanxi, mentioned in Chairman Xi's speech, is one of the important regional representatives of the western economic belt in China including 12 provinces and 2 autonomous regions, a vital component of China' s "Great West Development" initiative, and one of the significant source land and main area of Silk Road Economic Belt of the $B \& R$ initiative. In order to adapt to the $B \& R$ initiative and improve the comprehensive national power, China should possess fairly strong competitive advantages. Competitive advantages mainly depend on scientific technology and education, and fostering innovation and entrepreneurship talents is an important means to promote the competitive advantages in short order. Western colleges and universities in China, the education participants in the major area of The Belt and Road, should accurately understand the opportunities and challenges of the $B \& R$ initiative, proactively adapt to the transforming educational concept and mode, foster high-level innovation and entrepreneurship talents for the western regions in China, and consciously undertake the glorious mission that the national initiative endowed with.

\section{The SignificANCE OF B\&R INITIATIVE ON INNOVATION AND ENTREPRENEURSHIP EDUCATION IN WESTERN COLLEGES AND UNIVERSITIES}

The B\&R initiative enhances the pertinence of innovation and entrepreneurship educational mode in western colleges and universities. Chairman Xi Jinping points out in his speech at the Belt and Road Forum for International Cooperation, "we will be building Belt and Road Initiative into the road of innovation. Innovation is an importance force to promote development. Belt and Road construction itself is an initiative and is driven by innovation." This requires that when western colleges and universities foster the professional talents to adapt to the B\&R initiative, they should attach great importance to innovation: producing innovative knowledge, fostering innovative talents, and creating innovative atmosphere. Innovation and entrepreneurship education in western colleges and universities should be aiming at innovation-driven hightechnology and frontier at home and abroad in terms of scientific research direction, aiming at students' awareness in innovation and entrepreneurship in terms of educational concept, aiming at exploring the educational methods of innovation and entrepreneurship in terms of educational method, and effectively improve the pertinence and accuracy of innovation and entrepreneurship education.

The $\mathrm{B} \& \mathrm{R}$ initiative promotes the levels of innovation and entrepreneurship educational mode in western colleges and universities. The B\&R initiative integrate the world economy, politics and culture. Based on equality and mutual benefits, it conforms to the political needs of different countries in East Asia, Central Asia, West Asia, Europe and Africa, wins the active supports from the countries along the route, which make those countries and regions alongside benefit from their cooperation and develop in their cooperation. In the meantime, by means of the $B \& R$ initiative, countries along the $B \& R$ spread their new concepts, ideas and thoughts through 
economic and cultural intercourse, each making what the other lacks, and formed an organic whole. As the participant of the $\mathrm{B} \& \mathrm{R}$ initiative, innovation and entrepreneurship education in western colleges and universities realized the aim of "going out" and "bringing in" through cooperation, and established a global vision to carry on innovation and entrepreneurship education. The new concept to achieve innovation and entrepreneurship education with the mind of going with the world development strategy will provide a golden opportunity for the transforming of the innovation and entrepreneurship education ideas in western colleges and universities, and effectively promote the levels of the western colleges and universities.

The $\mathrm{B} \& \mathrm{R}$ initiative expands the spatiality of the innovation and entrepreneurship resources in western colleges and universities. Being the head and core area of Silk Road Economic Belt, western colleges and universities is the rear home of Maritime Silk Road as well and possess the innate regional advantage. In the course of the $B \& R$ initiative construction and development, western colleges and universities have more opportunities to communicate with worldwide prestigious colleges and universities, research institutes, enterprises, draw on each other' $\mathrm{s}$ merits. In the overall situation of the B\&R initiative countries and regions, innovation and entrepreneurship education in western colleges and universities could absorb all kinds of advanced technology, bring in advanced educational talents, expand the spatiality of the innovation and entrepreneurship resources in western colleges and universities, and finally realize the high standard communication "speaking to the world".

The B\&R initiative speeds up the openness of the innovation and entrepreneurship educational concept in western colleges and universities. Chairman Xi Jinping points out "we should establish multi-level mechanism for cultural cooperation, set up more platforms for cooperation, and open up more channels for cooperation." He also demands to promote educational cooperation including enlarging the scale of exchange students and improving cooperative education level. During the communications within the B\&R initiative, educational communication in particular, western colleges and universities have more opportunities to communicate and cooperate with countries along the Belt and Road, set up more channels for cooperation, derive the nutrition of multi-culture that is beneficial to the development of western colleges and universities and in line with China's national condition in terms of innovation and entrepreneurship education, work hard to establish the open, inclusive, cooperative and win-win innovation and entrepreneurship educational mode, and finally speeds up the openness and diversity of the innovation and entrepreneurship educational concept in western colleges and universities.

The B\&R initiative enriches the diversity of the innovation and entrepreneurship educational products in western colleges and universities. Being the source area of Silk Road Economic Belt, western colleges and universities possess the unique regional and historical advantage and provide good opportunity to further explore the realistic value of Silk Road Economic Belt in the historical perspective. In this perspective, innovation and entrepreneurship education in western colleges and universities could develop $B \& R$ souvenir, expand $B \& R$ culture, start $B \& R$ tourism, carry out $B \& R$ academic research, build entrepreneurship brand and program, and finally form the historic B\&R innovation and entrepreneurship mode.

\section{ANAlysis Of The Fitness BetweEn ThE B\&R INITIATIVE AND INNOVATION AND ENTREPRENEURSHIP EDUCATION IN WESTERN COLLEGES AND UNIVERSITIES}

The combination of the B\&R initiative and innovation and entrepreneurship education in western colleges and universities stems from their total fitness and is of great significance. It is necessary and feasible to put innovation and entrepreneurship education in western colleges and universities into the $B \& R$ initiative for development and good results.

The concept of "joint consultation, joint construction and sharing" of the B\&R initiative perfectly fit the innovation and entrepreneurship educational concept in western colleges and universities. First of all, the principle of sharing fit the innovation and entrepreneurship educational concept in western colleges and universities. China puts forward the B\&R initiative to achieve the goal of the new normal of peace and development on the basis of free navigation and free land access. With the principle of "joint consultation, joint construction and sharing", China will finally make the countries along the Road and Belt into a community of shared future. At the meantime, the purpose of the innovation and entrepreneurship education in western colleges and universities absorbing the advanced concept and educational experiences of the western areas and countries along the Belt and Road, is to achieve educational achievement sharing, educational technology sharing and educational experiences sharing and to build a community of innovation and entrepreneurship education. Secondly, the principle of "joint consultation, joint construction" fit the principle of cooperation and development of the innovation and entrepreneurship education in western colleges and universities. In order to realize the full and healthy development of the economic society, the B\&R initiative have to adhere to the principle of "joint consultation, joint construction" for development on the basis of equality, stick to respect each country' s sovereignty and national dignity, carry out cooperation according to the international law and national convention, and set a brand new example of the new international economic order and regional cooperation. Likewise, in order to realize the full and healthy development, innovation and entrepreneurship education in western colleges and universities also have to stick to the principle of equality and consultation between western colleges and universities, national colleges and universities, domestic and foreign colleges and universities, colleges and universities and social organizations, undertake the due obligation, realize equal and cooperative mode, and jointly develop innovation and entrepreneurship education according to the concept of "joint consultation, joint construction".

Rational cognition should be conducted on both the B\&R initiative and innovation and entrepreneurship education with the law of "unity of opposites" for contradiction. According to the dialectical materialism, law of contradiction, namely, law of "unity of opposites" is the most fundamental law of 
materialistic dialectics. The identity and belligerence of the contradiction are the basic features of the development of the contradiction in things. Understanding the identity and belligerence principle of the contradiction correctly and reasonably will achieve the transforming of the two aspects of contradiction. The B\&R initiative is both an opportunity and challenge for countries and regions along the Silk Road. On the one hand, they have more chances to take part in the development of the Belt and Road under the background of economic globalization; on the other hand, they will face negative factors that the competition of the foreign economy brings. Only through correctly understanding the opportunity and challenge of the $B \& R$ initiative, constantly strengthening cooperation and communication, reform of the economic system and relations of production, can countries and regions along the Silk Road turn the belligerence of the contradiction into the identity, thus promote the coordinated and balanced economic growth of the countries and regions along the Silk Road. Under the background of the B\&R initiative, innovation and entrepreneurship education in western colleges and universities also faces opportunities and challenges. Economy, politics and culture help transform the factors like concept and cognition of innovation and entrepreneurship education; meanwhile they bring challenges in terms of quality and speed that innovation and entrepreneurship education in western colleges adapt to the B\&R initiative. They even bring enormous impacts to the parts of the lagging educational concept.

The driving force between the $B \& R$ initiative and innovation and entrepreneurship education in western colleges and universities originates from the philosophical contradiction of internal and external causes. According to the dialectical materialism, internal cause is the basic reason causing evolvement, and the external cause is the condition causing evolvement. Evolvement is the result of interaction between internal and external causes. The proposal of the B\&R initiative is a response to the impact of economic globalization in view of history and reality and under the background of the "new normal "of China's economic development. It aims at accelerating the integration of world economy and constructing new international economic order through regional economic cooperation. In order to obtain the prospective economic and cultural benefits in the $B \& R$ initiative, related countries and regions should not only attach importance to the cooperation and communication with other countries and regions, but also proactively stick to the developmental quality of self-reliance and struggling to achieve the true sense of "sharing". In the meantime, there is fitness in terms of driving force between innovation and entrepreneurship educational development in western colleges and universities and the development of B\&R initiative countries and regions. In order to meet the anticipated educational effects and achievement, innovation and entrepreneurship education in western colleges and universities should not only closely cooperate with central, eastern regions and B\&R line countries, learning from other' s strong points to offset own weakness, but more importantly carry forward the spirit of self-reliance and struggling, work hard to establish the regional brand among western colleges and universities, and explore their own innovation and entrepreneurship educational mode to achieve "temporary victory" in innovation and entrepreneurship education.

The B\&R initiative and innovation and entrepreneurship education in western colleges and universities share the common goal. Chairman Xi Jinping once pointed out that the Silk Road Economic Belt was designed to bring European and Asian countries more closely in economy, more deeply in cooperation and more widely in development space. We could employ creative and cooperative mode to build Silk Road Economic Belt together. Chairman Xi' s statement reveals the original mission of the $\mathrm{B} \& \mathrm{R}$ initiative, namely, the initial economic communication and cooperation help to further promote cooperation in other fields, and finally achieve constructing the situation of peace and sharing. In the process of economic cooperation, as a market player, every related country taking part in the construction of Silk Road Economic Belt inevitably demand their own benefits in cooperation, otherwise there is no necessity to cooperate and communicate. In order to make substantial progress, innovation and entrepreneurship education in western colleges and universities needs to carry our necessary communication and cooperation between the west and the mid-east, the west and the abroad, universities and universities, universities and enterprises. Their cooperation should base on mutual benefits and development, otherwise there is no necessity to cooperate and communicate. The only difference is that in the cooperation of innovation and entrepreneurship education the economic benefits can not rise to the primary to certain extent, and usually hidden benefits or long-term benefits are the common counterparts, but still follows the exchange law of the market player.

\section{THE DEVELOPMENTAL ROUTE OF INNOVATION AND ENTREPRENEURSHIP EDUCATION IN WESTERN COLLEGES AND UNIVERSITIES UNDER THE BACKGROUND OF THE B\&R INITIATIVE}

The B\&R initiative is both an opportunity and challenge for innovation and entrepreneurship education in western colleges and universities. But on a whole, if the western colleges and universities could accurately respond to the developmental trend of the era and utilize the law of development, opportunity will become the principle aspect of contradiction, and under given conditions, challenge will turn into opportunity. Innovation and entrepreneurship education in western colleges and universities should seize the opportunity of the B\&R initiative, constantly explore the new educational route, promote the innovation and entrepreneurship education around the B\&R initiative, and establish the distinctive innovation and entrepreneurship education.

Setting up global view and enhancing strategic vision. First of all, innovation and entrepreneurship education organizations in western colleges and universities should set up a global view. On the basis of regional economic cooperation, the B\&R initiative carries out multi-angled and all-round cooperation covering culture, education, environment, transportation, politics, etc., and it further promote the global cooperation through regional cooperation, and establish the human economic community and a community of human common destiny. Western colleges and universities should enhance 
global view proactively, foster innovation and entrepreneurship talents with a global vision focusing on the integrated talents of economy, finance, transportation, language, etc., and help students set up a global view of innovation and entrepreneurship. Secondly, innovation and entrepreneurship education needs long-term strategic vision and awareness. The realization route of the $B \& R$ initiative should start from regional economic cooperation, further promote the cooperation in other fields, and finally rise to the political height to construct a community of common destiny. However, the economic development of countries along the Belt and Road like Middle East, Central Asia, and African Areas is facing different kinds of constraints, even development bottleneck. Therefore, to achieve the goal of the B\&R initiative is a long and difficult process. Innovation and entrepreneurship education organizations in western colleges and universities should fully consider that innovation and entrepreneurship aims at fostering global talents and is ready for the long-term and complicated preparation in fostering. Western colleges and universities should possess a global and strategic vision to foster innovation and entrepreneurship talents, constantly promote talents' global adaptability and the ability of dealing with complexity, so that the quality of talents could be constantly enhanced to meet the background of the $B \& R$ initiative.

Keeping region-oriented and excavating regional features. First of all, in the process of innovation and entrepreneurship education, western colleges and universities should also firmly grasp the historic regional feature that the west is the starting point of Silk Road, constantly guide the educates to explore and excavate historic culture, stories and relics of the starting point of Silk Road, set up new products and new culture of the starting point of Silk Road, and build Silk Road products of historic profundity and cultural connotation. Secondly, western colleges and universities should also take the advantage of academic research, together with the features of the starting point of Silk Road to hold global high-level innovation and entrepreneurship academic forum and introduce the most advanced academic view and scientific technology all over the world to provide intellectual and technological support for the innovation and entrepreneurship in the west. Finally, western colleges and universities should fully excavate humanity and natural resources like ancient cities, historic cities, tourism cities, efficiently integrate all the resources, carry out the industry-university-research organic cooperation, establish large-scale, intensified, and modern innovation and entrepreneurship model of the tourist industry, constantly develop the western tourism with innovation and entrepreneurship concept, promote the whole western region to achieve grand development of the tourism economy and development in other fields against the B\&R initiative.

Seizing the transition opportunity and promoting the university management. The B\&R initiative will certainly bring opportunities and challenges for innovation and entrepreneurship education in western colleges and universities. Western colleges and universities should accurately grasp the opportunities through obtaining the advanced experiences of innovation and entrepreneurship education in and abroad in communication and cooperation, constantly carrying out the educational transition of their own, and promoting their own innovation and entrepreneurship education to meet the need of the development of the $B \& R$ initiative. In the meantime, the $\mathrm{B} \& \mathrm{R}$ initiative will also has impacts on the original innovation and entrepreneurship educational mode, concept, method, resource, etc. of the western colleges and universities, forces the western colleges and universities to transform their disadvantages, optimize allocation of resources, perfect institutional structure, innovate educational concepts. Western colleges and universities should consciously take the challenges for opportunities, meet the challenges through a variety of ways, turn the challenges into opportunities with the methodology of contradiction, and improve the educational level of their own.

Grasping the pulse of the times and utilizing the policy bonus. In order to achieve the $\mathrm{B} \& \mathrm{R}$ initiative well, China successively made a great deal of policies and measures on different levels of central government, ministries and commissions, and local government to promote the B\&R initiative. For example, The Development Plan and Action Plan of Qinghai Silk Road Cultural Industry Belt (2018-2025) is mainly to establish the industrial culture with Qinghai characteristic; The Working Plan (2018-2020) of the Southern Channel of Gansu Cooperative Sino-Signore Interconnectivity Program issued by the general office of Gansu provincial government put forward that Lanzhou-Chongqing railway and the main logistics nodes of Gansu should be utilized to connect Central Asia, Southern Asia and Europe and then build compound international trade logistics channel organically linking the Belt and Road; Shaanxi Action Plan of 2016 B\&R Construction will promote the B\&R Construction in the aspects of building transportation and commerce logistics center, international production capacity cooperation center, science and education center, tourism and finance center, strengthening national ecological security defense, establishing an opening economic situation. What is more, there are projects, programs, policies, and measures that many governments in and abroad appointed for the development of the B\&R initiative. Western colleges and universities should fully grasp and utilize the existing policies, constantly absorb resources, gather power, grasp the pulse of the times, promote the innovation and entrepreneurship education cause to meet the need of the development of the $B \& R$ initiative within the policy context, and foster more excellent talents and brand programs for the development of the $\mathrm{B} \& \mathrm{R}$ initiative.

Establishing institutional system and long-term mechanism. Colleges and universities are the cooperative institutions of industry-university-research. In the developing process, abundant academic achievements and intellectual property will inevitably take shape. Western colleges and universities should work out refined measures and methods in both the university and academic perspective to protect intellectual property within the law and policy context, establish systems that stimulate the innovation and entrepreneurship achievements, complete and revise the systems and measures that can not adapt to the development of the B\&R initiative, build a vibrant atmosphere of innovation and entrepreneurship, and improve the enthusiasm and initiative of innovation and entrepreneurship. 


\section{CONCLUSION}

To sum up, the B\&R initiative will certainly bring opportunities and challenges for innovation and entrepreneurship education in western colleges and universities. Western colleges and universities should seize the momentum, constantly transform their concept in working, contribute to the talent-fostering for the $\mathrm{B} \& \mathrm{R}$ initiative, and commit to the constructing a community of human common destiny that the Party and the country put forward.

(1)(3) Xi Jinping: the Governance of China (Volume I) Work Together to build the Silk Road Economic Belt Page 287

(2) Xi Jinping: the Governance of China (Volume II) Work Hand in Hand to Build Belt and Road Page 506

\section{REFERENCES}

[1] Dai Renqing. On the route of innovation and entrepreneurship talent fostering in colleges and universities in northern Jiangsu against B\&R initiative [J]. Journal of City College of Vocational Technology, 2017 (2).

[2] Zhang Yansheng, Wang Haifeng, Yang Kunfeng. Challenges and Countermeasures for Constructing the Belt and Road [J]. Macroeconomic Study, 2017 (11).

[3] Gan Yue, Zhou Guping. Cultivation of the innovation and entrepreneurship and structural reform talents against B\&R initiative [J]. Educational Research, 2016 (10).

[4] Bi Yaqin, Li Weidong. Comparative study on Sino-American innovation and entrepreneurship education in cultural vision $[\mathrm{J}]$. Journal of Changchun Normal University, 2018 (1).

[5] Wang Yongyou, Zhang Xueliang. Correct value guidance of innovation and entrepreneurship education in colleges and universities [J]. Higher Education in China, 2017 (23).

[6] Li Deping. Construction route of entrepreneurship culture in colleges and universities in vision of cultural education [J]. Journal of East China Institute of Technology, 2017 (4). 